Radosław Kuliniak

Uniwersytet Wrocławski, Wrocław

ORCID: 0000-0002-0090-6609

e-mail: kornik90@poczta.onet.pl

\title{
Wprowadzenie do polemiki Romana Witolda Ingardena z Leonem Chwistkiem*
}

W 1921 roku na rynku wydawniczym pojawiła się praca głównego teoretyka artystycznej grupy formistów - Leona Chwistka, zatytułowana Wielość rzeczywistości $i^{1}$. Był on w tym czasie nauczycielem krakowskiego gimnazjum im. Jana Sobieskiego, z doktoratem napisanym u Władysława Heinricha z logiki matematycznej i obronionym na Uniwersytecie Jagiellońskim. Niezadowolony z pracy w szkolnictwie średnim, zdobytej dzięki naleganiom i protekcji wuja ${ }^{2}$, szukał refugium w twórczości artystycznej. Ostatecznie schronił się przed trudem pracy gimnazjalnej w swoim krakowskim środowisku. Choć tamtejsi filozofowie i matematycy mu nie sprzyjali, habilitował się w 1928 roku z logiki matematycznej. Umożliwiono mu to pod warunkiem, że nie będzie starał się w przy-

* Niniejsze rozważania powstały na podstawie wcześniejszych uwag na ten sam temat zawartych w: Radosław Kuliniak, Mariusz Pandura, Jestem filozofem świata -

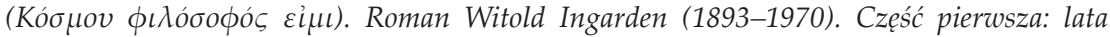
1893-1938 (Kęty: Wydawnictwo Marek Derewiecki, 2019), 370-379. Teksty zasadniczo nie różnią się od siebie.

1 Zob. Leon Chwistek, Wielość rzeczywistości (Kraków-Jasło: Zakład Graficzny „Wisłoka”, 1921). Zob. przedruk w: Leon Chwistek, Pisma filozoficzne i logiczne, t. 1 (Warszawa: Państwowe Wydawnictwo Naukowe, 1961), 1-105.

2 Zob. Karol Estreicher, Leon Chwistek. Biografia artysty (Kraków: Państwowe Wydawnictwo Naukowe 1971), 47. 
szłości o katedrę w Krakowie ${ }^{3}$. Złamanie tego przyrzeczenia nie było potrzebne. Szwagier Chwistka, Hugo Steinhaus, wkrótce wywalczył dla niego posadę na Uniwersytecie Jana Kazimierza we Lwowie. Stało się to pomimo głębokiego sprzeciwu Kazimierza Twardowskiego, który został powołany do oceny ubiegających się o posadę i widział na tym stanowisku innego kandydata - Alfred Tarskiego. Ostatecznie Chwistek został zatrudniony nie na Wydziale Humanistycznym, lecz Matematyczno-Przyrodniczym, jako logik, a nie filozof. Filozofia była jednak tym kierunkiem, w którym Chwistek uważał się za znawcę. Wielu zaś specjalistów wskazywało, że powinien porzucić myśl o zajmowaniu się tą dziedziną.

Jednym z pierwszych siedmiomilowych kroków Chwistka na drodze do kariery filozoficznej miały być prace poświęcone wielości rzeczywistości. Chwistek nie miał jednak niezbędnych, porządnych, filozoficznych siedmiomilowych butów. Poza tym nawet $\mathrm{w}$ środowisku krakowskich filozofów zajmował dosyć specyficzną pozycję. Na studiach pierwotnie ukierunkowany był na matematykę i fizykę, w późniejszych latach zainteresował się psychologią i filozofią. Wysforował się nawet na przewodniczącego koła filozofów. W owym czasie popierał go tracący już wpływy sybaryta Stefan Pawlicki. Ta trampolina do wybicia się w środowisku naukowym okazała się jednak złudna. Pawlicki w 1916 roku zmarł, a ze swoim promotorem Heinrichem Chwistek głęboko się poróżnił.

Opublikowana przez Chwistka praca dotyczyła filozoficznej teorii różnorodności rzeczywistości. Chwistek wyróżniał jej cztery rodzaje, tj. rzeczywistość w ogólnym rozumieniu, rzeczywistość fizyczną, rzeczywistość fenomenologiczną i rzeczywistość wizjonerską (intuicyjną) ${ }^{4}$. Ingarden zainteresował się tą pracą z racji swoich fenomenologicznych preferencji. Wiedział, że Chwistek występuje w niej przeciwko Husserlowi i Bergsonowi. Ingarden musiał też nieco usłyszeć o Chwistku podczas swoich pobytów w Krakowie w trakcie wielkiej wojny, zwłaszcza gdy uczestniczył w seminarium filozoficznym Tadeusza Garbowskiego na Uniwersytecie Jagiellońskim w 1915 roku. Ingarden znał pewnie Chwistka również z opowieści swoich starszych kolegów z Królewskiego Uniwersytetu Jerzego Augusta w Getyndze, gdzie Chwistek przebywał krótko w semestrze letnim 1909 roku, podając się za Polaka z Ameryki, urodzonego w Chicago ${ }^{5}$. Informatorem był dla niego z pewnością Aleksander Rosenblum, który studiował w tym samym czasie filozofię

3 Zob. tamże, 205.

4 Zob. Chwistek, Pisma filozoficzne i logiczne, t. 1, 54-55.

5 Zob. Amtliches Verzeichnis des Personals und der Studierenden der Königl, GeorgAugust-Universität zu Göttingen. Auf das halbe Jahr von Ostern 1909 bis Michaelis 1909 (Göttingen: Dieterich'sche Univ.-Buchdruckerei, 1909), 45. 
na tej uczelni, wraz z Ireną Fryling, którą miał poślubić pół roku później6. Znajomość Rosenblumów z Chwistkiem była utrzymywana w następnych latach. Chwistek kilka lat później, podczas pobytu w Paryżu, namalował portret Ireny Fryling-Rosenblumowej ${ }^{7}$.

Podczas pobytu w Getyndze nie wsławił się niczym wielkim. Został wysłany, aby bliżej poznać getyńską matematykę i fizykę. Przeżywał jednak okres niewiary w możliwości poznawcze nauki. Bardziej interesowały go techniki malarskie, studia nad rysunkiem, które później kontynuował w Paryżu. Zapisany na getyński uniwersytet, jako student nauk przyrodniczych, filozofię studiował dorywczo, nisko oceniając tamtejszych filozofów. Krytycznie wypowiadał się między innymi o Husserlu, uważając, że choć pedantycznie przygotowywał swoje wykłady, to były one przegadane, a przy tym fenomenolog przedstawiał swoje rzekomo wielkie odkrycia spraw, które od dawna były znane ${ }^{8}$. W ten sposób Chwistek podsumował wykłady Husserla „Einführung in die Phänomenologie der Erkenntnis"' ${ }^{\prime \prime}$. Suchej nitki nie zostawiał także na uczniach Husserla, uznając ich za "stado", ślepo idące za wykładowca, jak za przewodnikiem ${ }^{10}$. Dopiero odczyt Henriego Poincarégo z 27 kwietnia 1909 roku o liczbach pozaskończonych dodał Chwistkowi wiatru w żagle. Chwistek zdecydował się wówczas poświęcić logice ${ }^{11}$. Getynga okazała się ważna w jego życiu także z innego powodu - tam poznał dwa ważne filary swojej kariery naukowej, swoich dwóch przyszłych szwagrów - Hugona Steinhausa i Włodzimierza Stożka ${ }^{12}$.

W ówczesnym środowisku filozoficznym Chwistek nie miał najlepszej reputacji. Nie zyskał uznania zwłaszcza w oczach Twardowskiego, który traktował go uprzejmie, lecz z dystansem. Nie bez znaczenia był fakt, że Chwistek sprzątnął kuzynowi Twardowskiego sprzed nosa potencjalną żonę, Olgę Steinhausównęę, i sam się z nią ożenił. To właśnie Olga Chwistkowa, dawna studentka Twardowskiego, przedstawiła

6 Zob. tamże, 75 (Aleksander Rosenblum) oraz 90 (Irena Fryling).

7 Zob. Czesław Głombik, Husserl i Polacy. Pierwsze spotkania, wczesne reakcje (Katowice: Wydawnictwo Gnome, 1999), 24-25.

${ }^{8}$ Zob. Estreicher, Leon Chwistek, 60.

9 Zob. Karl Schuhmann, Husserl-Chronik. Denk- und Lebensweg Edmund Husserls (Den Haag: Martinus Nijhoff, 1977), 125. Tekst wykładu został opublikowany w: Edmund Husserl, Einführung in die Phänomenologie der Erkenntnis, hrsg. v. Elisabeth Schuhmann (Dordrecht: Springer, 2005).

10 Zob. Estreicher, Leon Chwistek, 60.

11 Zob. Roman Murawski, Filozofia matematyki i logiki w Polsce międzywojennej (Toruń: Wydawnictwo Naukowe Uniwersytetu Mikołaja Kopernika, 2011), 58; Reinhard Kahle, Poincaré in Göttingen, w: Poincaré, Philosopher of Science. Problems and Perspectives, M. de Paz, R. DiSalle (eds.) (Dordrecht: Springer (etc.), 2014), 90, 93.

12 Zob. Amtliches Verzeichnis des Personals [1909], 81-82.

13 Zob. Alina Dawidowiczowa, "Zeschnięte liście i kwiat...". Wspomnienia (Kraków: Wydawnictwo Literackie, 1989), 37-38. 
swojego męża profesorowi podczas podróży z Poronina do Krakowa 26 sierpnia 1919 roku $^{14}$. Później Twardowski kilkakrotnie stawał Chwistkowi na drodze jego kariery. Można podejrzewać, że żywił do niego pewną niechęć. Musiał go tolerować jako szwagra Hugona Steinhausa, doskonałego matematyka lwowskiego ${ }^{15}$. Twardowski czytał prace Chwistka, zwłaszcza filozoficzne. Po ukazaniu się Wielości rzeczywwistości chętnie przystał na propozycję Ingardena dotyczącą napisania przez niego polemicznej recenzji. Można podejrzewać, że i tak sam wpłynąłby na któregoś ze swoich podopiecznych, aby zrecenzował tę pracę. Ingarden wykonał ruch wyprzedzający, co spodobało się Twardowskiemu. Lubił młodych, zdolnych, myślących i przewidujących filozofów. Pomagał im i sprzyjał ich pomysłom. W sprawie Chwistka pokierował Ingardenem, zalecając mu najpierw lekturę recenzji jego pracy, która ukazała się na łamach efemerydy formistów, Nowej Sztuki ${ }^{16}$. Pisał o tym Twardowski Ingardenowi w krótkim liście z 26 marca 1922 roku:

Nawiązując do wyrażonej w mym ostatnim liście prośby o napisanie recenzji dla Ruchu Filozoficznego z książki Chwistka pt. Wielość rzeczywistości, donoszę, że wpadł mi w rękę wydany w listopadzie zeszłego roku numer 1. czasopisma Nowa Sztuka z entuzjastycznym sprawozdaniem o tej książce. Może się Panu Doktorowi ta wiadomość, o ile nie miał jej już, na coś przyda ${ }^{17}$.

Ingarden skorzystał z podpowiedzi Twardowskiego. Przystąpił do polemiki z Chwistkiem. Szybko napisał swoją recenzję i dzięki pomocy Władysława Witwickiego zamieścił ją w Przegladzie Filozoficznym ${ }^{18}$. Ingarden nie znał bliżej Chwistka. Nikt go również nie ostrzegł przed jego wybuchowym charakterem. Co prawda słyszał on o jego nagłośnionym $\mathrm{w}$ prasie pojedynku paryskim, lecz wówczas nikt już nie traktował tej sprawy poważnie. Niesłusznie. Jak się później okazało, Chwistek w swojej zapalczywości wobec krytyki bywał nieobliczalny. Kilka lat później wyzwał na pojedynek krakowskiego chirurga Glatzla, swojego

14 Zob. Kazmierz Twardowski, Dzienniki, oprac. Ryszard Jadczak, cz. 1: 1915-1927 (Toruń: Wydawnictwo Adam Marszałek, 2001), nota z 26 sierpnia 1919 roku, 123.

15 Szerzej o tym traktuje Ryszard Palacz, „Rozdział XXVI. Leon Chwistek, czyli o wielości rzeczywistości", w: Klasycy filozofii polskiej (Warszawa-Zielona Góra: Zachodnie Centrum Organizacji, 1999), 299-314.

16 W miesięczniku krakowskim Nowa Sztuka, R. I, listopad 1921 roku, z. 1, s. 30-31, ukazała się chwaląca pracę Chwistka recenzja. Nie wiadomo, kto był jej autorem. Wiemy jednak, kto zasiadał w komitecie redakcyjnym tego czasopisma - nie kto inny, jak Leon Chwistek.

17 Zob. list Kazimierza Twardowskiego do Romana Witolda Ingardena z 26 marca 1922 roku, w: ARI.

18 Zob. recenzję Ingardena z pracy Chwistka, Wielość rzeczywwistości, Kraków 1921, która ukazała się w Przeglądzie Filozoficznym 25, 3 (1922): 451-468. 
kolegę z Uniwersytetu Jagiellońskiego, za to, że ten miał wyrazić się niepochlebnie o sztuce współczesnej. Jak wówczas w Krakowie mówiono, Chwistek „,był pierwszym człowiekiem, który zoperował Glatzla” ${ }^{19}$. Niebezpieczeństwo było realne, a tego Ingarden nie był świadom.

Ingarden w swojej recenzji sięgnął nie tylko do Wielości rzeczywistości. Czytał wcześniejszą pracę Chwistka O wielości rzeczywistości w sztuce z 1918 roku $^{20}$. Poglądy krakowskiego badacza nie zrobiły na nim dobrego wrażenia. Recenzja nie była jednak napastliwa, Ingarden napisał ją z dużą dozą życzliwości. Słowa płyną w niej niczym bystra woda. Znał co prawda wynaturzoną recenzję z Nowej Sztuki i pochlebne opinie Kotarbińskiego ${ }^{21}$. Nie chciał być jednak stronniczy i przedstawił opis zgodny ze stanem rzeczy. Nie spodziewał się ataku ze strony Chwistka, lecz ewentualnie dalszej polemiki. Recenzję Ingardena czyta się dobrze. Jest to tekst rzeczowy i miarodajny, który w niczym nie uchybia Chwistkowi. Najbardziej fachowa wydaje się konkluzja. Ingarden miał zresztą w zwyczaju czynić doskonałe, syntetyczne podsumowania - nie inaczej stało się tym razem. Zapisał on:

Jeszcze jedna drobna uwaga, spowodowana pewnym zadaniem recenzji prof. Kotarbińskiego, na którą zresztą się najzupełniej godzimy. Prof. Kotarbiński stwierdza, że cenną i interesującą częścią rozprawy jest zastosowanie głównej tezy Wielości rzeczywistości do teorii sztuki. I niewątpliwie samo zagadnienie wyróżnienia zasadniczych typów (stylów) dzieła sztuki, zastanowienia się nad tym, czy każdemu z nich odpowiada jakaś szczególna dziedzina rzeczywistości, względnie jakiś szczególny obraz świata, związany z taką czy inną postawą poznawczą podmiotu, samo to zagadnienie jest bardzo ciekawe dla historii sztuki i bardzo ważne. Lecz znów aparat metodyczny, za pomocą którego autor stara się je rozwiązać, jest wysoce niezadawalający. Abstrahujemy już od tego, że należałoby do tego celu mieć wyjaśnione naprawdę zasadnicze przynajmniej zagadnienie teorii rzeczywistości, czego nam książka Dr. Chwistka, niestety, nie daje. Lecz przede wszystkim trzeba by się postarać o bogaty materiał z zakresu historii sztuki, przeprowadzić rozległe porównawcze studia na tak zebranym naocznym materiale, który należałoby czytelnikowi w reprodukcjach przedstawić, trzeba by pokazać, czy pewne style posiadają szczególne cechy charakterystyczne, mające swe odpowiedniki w takiej czy innej rzeczywistości. Wywody autora pozbawione tego wszystkiego tracą co najmniej swą siłą przekonywającą i rzeczowo udowadniane nie sa. Że sprawa nie jest tak łatwa, jak to autor daje się sądzić, pouczyła

${ }^{19}$ Dawidowiczowa, "Zeschnięte liście i kwiat...", 59-60. Zob. też Estreicher, Leon Chwistek, 100.

${ }^{20}$ Zob. Leon Chwistek, „Wielość rzeczywistości w sztuce”, Maski 1-4 (1918), 38-58. Zob. przedruk w Leon Chwistek, Wybór pism estetycznych, oprac. Teresa Kostyrko (Kraków: Universitas, 2004), 3-20.

${ }^{21}$ Zob. Tadeusz Kotarbiński, „Leon Chwistek: Wielość rzeczywistości” (recenzja), Przeglad Warszawski 6 (1922): 426-428. 
mnie o tym niegdyś książka prof. Wölflina pt. Kunstgeschichtliche Grudbegriffe, na którą pozwalam sobie autorowi zwrócić uwagę. Książka ta liczy kilkaset stron, zaopatrzona jest w liczne reprodukcje, a stawia sobie za zadanie ustalić tylko kilka punktów różnicy pomiędzy dwoma stylami. Mam wrażenie, że gdyby autor był wszedł na drogę takich historyczno-porównawczych studiów, nie twierdziłby może, że realistyczne dzieła sztuki odtwarzają rzeczywistość fizykalną22.

Po zamieszczeniu swojej recenzji w Przegladzie Filozoficznym Ingarden zabrał się do kolejnych prac. Myślał o kontynuacji przerwanych badań nad problemem istoty poznania świata realnego zewnętrzne$\mathrm{go}^{23}$. Chciał dokończyć drugą część rozprawy Über die Gefahr einer Petitio Principii in der Erkentnistheorie ${ }^{24}$. Wkrótce do Torunia dotarła wiadomość od Witwickiego, że w czwartym numerze Przegladu Filozoficznego z 1922 roku Chwistek zamierza replikować w sprawie recenzji Ingardena $^{25}$. Donosił, że zapowiada się ciekawa dyskusja dwóch młodych adeptów filozofii, jakiej Przeglad Filozoficzny dawno nie widział. Był tylko jeden problem. Został zaburzony układ sił. Redakcja zamierzała opublikować odpowiedź Chwistka, nie dając przy tym szansy repliki w tym samym numerze Ingardenowi. Witwicki pisał do Ingardena, że na ten temat rozmawiał już z Marianem Borowskim i Kazimierzem Błeszyńskim. Obaj interlokutorzy umyli jednak ręce, twierdząc, że nie mogą nic zrobić. W liście Witwickiego z 25 lutego 1922 roku czytamy:

Jeszcze na dzień przed odebraniem Twojej kartki ostatniej przyszedł do mnie do Zakładu Borowski przejrzeć książki nowe. Siada na kanapie i czeka, co z nim będę gadał. Nie odrywając oczu od rysunków, które dla tachistoskopu robiłem, pytam go o Twą recenzję. Powiada mi: „Nie pójdzie teraz, aż w następnym numerze, bo wydrukowała mi drukarnia wcześniej, niż się spodziewałem, i wobec tego, chcąc uniknąć grożącego podwyższenia cennika, musiałem już nie dać jego odpowiedzi do druku, a tylko samego Chwistka, choć obiecałem Ingardenowi, że go umiesz-

22 Zob. Roman W. Ingarden, „Recenzja z pracy Leona Chwistka «Wielość rzeczywistości»", Kraków 1921, Przegląd Filozoficzny 25, 3 (1922): 467-468.

${ }^{23}$ W ARI znajdują się w "Spisie nieogłoszonych prac, szkiców, notatek z kwietnia 1928 roku" wpisy dotyczące wskazanego zagadnienia. Są to: Czy i jak można poznać obiektywność spostrzeżenia zewnętrznego? (z adnotacją: „II. redakcja odczytu na Zjeździe Filoz. W roku 1923, niedokończona, pisana ponownie na wiosnę roku 1925", 36); Streszczenie powyższego odczytu dla Pamiętnika Zjazdu 1923, 5; a także Czy i jak można wykazać obiektywność spostrzeżenia zew. (I. red. Odczytu, maj 1923 roku, s. 27). Wymienione prace są związane z referatem przygotowanym na I Zjazd Filozofów Polskich we Lwowie.

${ }^{24}$ Ingarden powrócił w tym momencie do pisania drugiej części wskazanej pracy, której redakcję rozpoczął i nie skończył wiosną 1919 roku. Tekst w ARI.

${ }_{25}$ Zob. list Władysława Witwickiego do Romana Witolda Ingardena z 25 lutego 1922 roku, w: ARI. 
czę". - „No dobrze, ależ Ingarden” - powiadam - „będzie się mógł słusznie czuć pokrzywdzony - tym bardziej, że Ci dał rękopis na żądany termin. - Przecież to krzywda" ${ }^{26}$.

Witwicki chciał, aby Ingarden zareagował na zaistniałą sytuację. Ten jednak przystał na warunki redakcji Przegladu Filozoficznego ${ }^{27}$. Poczekał na replikę Chwistka i dopiero wówczas odpowiedział w kolejnym numerze tego czasopisma w 1923 roku. Dodatkowo Witwicki napisał do Ingardena:

Nie zatelefonowałem, tylko przez woźnego zakładu posłałem mu [Borowskiemu] pisemną prośbę, żeby i Twój artykuł umieścił albo oba odłożył do następnego numeru. Dziś mu to posłałem do domu - wątpię, żeby to miało jakikolwiek skutek. Jakkolwiek wypadnie, nic sobie $\mathrm{z}$ tego nie rób - przecież co się do Przegladu posyła - to się do wiecznej rupieciarni wrzuca, którą i tak dopiero za sto lat ktoś przejrzy. A w osobiście nietaktownym stylu Chwistka każdy myślący czytelnik i tak się zorientuje. Nawet i bez odpowiedzi Twojej. Przecież nie myślisz, żeby ludzie myślący, przeczytawszy jego tytuł i treść jego recenzji zważywszy, nabrali przekonania, że Cię pognębił logicznie i moralnie. Tego nikt myślący i tak nie powie, a na głupich Ci zależy? Zrobiłeś, coś mógł - ja także myślę, że zrobiłem, com mógł - cóż więcej?28

Po tym liście Witwickiego nie pozostało Ingardenowi nic innego, jak tylko czekać na replikę Chwistka. Ukazała się ona w czwartym numerze Przegladu Filozoficznego z 1922 roku $^{29}$, jak zapowiadał Witwicki. Sprawdziły się jego przewidywania co do tytułu i objętości tej repliki. Potwierdziły się dodatkowo racje merytoryczne, które stały po stronie Ingardena. Nie bez znaczenia pozostał też styl, w jakim Chwistek atakował Ingardena. Trzeba powiedzieć wprost, że potraktował sprawę poważnie. Od pierwszych słów rzucił się na fenomenologa z impetem. Pisał:

W poprzednim numerze Przegladu Filozoficznego wystąpił Dr Roman Ingarden z „recenzją” mojej książki pt. Wielość rzeczywistości. „Recenzja” ta, utrzymana $\mathrm{w}$ tonie szkolnego patosu $\mathrm{z}$ nieodłącznym pluralis maiestaticus, jest widocznie zamierzona jako sprawiedliwe skarcenie nieświadomego rzeczy tubylca przez uczonego zagranicznej miary, wtajemniczonego w najdrobniejsze detale ruchu filozoficznego w Niemczech i gdzie

${ }^{26}$ Zob. tamże.

${ }_{27}$ Zob. listy Mariana Borowskiego do Romana Witolda Ingardena z początku 1922 roku, a dokładnie listy z 13 stycznia 1922 roku i 19 kwietnia 1922 roku, w: ARI.

${ }_{28}$ Zob. list Władysława Witwickiego do Romana Witolda Ingardena z 25 lutego 1922 roku, w: ARI.

29 Zob. Leon Chwistek, „Krótka rozprawa z panem Romanem Ingardenem, doktorem uniwersytetu fryburskiego", Przeglad Filozoficzny 25, 4 (1922): 540-544. 
indziej. W myśl tej zasady autor daleki od wysiłku wniknięcia w treść mojej książki stwierdza po prostu, że ja nie rozumiem lub nie znam omawianych autorów (Bergson, Husserl, Nietzsche, Poincaré), nie znam ważnych(?) rezultatów uzyskanych przez husserlistów w zakresie teorii rzeczywistości, nie orientuję się w problematyce logiki filozoficznej(?) i teorii poznania, poza tym zaś argumentuję w sposób prymitywny, niezasługujący na uwzględnienie ${ }^{30}$.

Ingardena początkowo dotknęły słowa Chwistka. Później przyszło uspokojenie. Uznał, że nie należy się przejmować jawnym odwetem. Postanowił sprawę zbagatelizować i nie ciągnąć dalej. Zmienił jednak zdanie po kolejnych listach wymienionych $\mathrm{z}$ Witwickim ${ }^{31}$. W jednym $\mathrm{z}$ nich przeczytał:

Bardzo się cieszę z tego, żeś się Chwistkiem zajął i napisałeś to, co mu się dawno należało. Kiedyś we Lwowie miałem szaloną ochotę wziąć się do niego, kiedy się w Maskach te cztery rzeczywistości ukazały, ale skończyło się na ochocie. I oto Chwistek, opublikowawszy jeszcze Nuż w brzuchu i projekt połamanego hotelu w Zakopanem oraz blagierski wstęp do katalogu formistów, kandyduje na katedrę filozofii w Warszawie i znajduje w Leśniewskim zagorzałego zwolennika. Ja, osobiście, mam wrażenie, że mamy tu do czynienia $\mathrm{z}$ bolszewizmem filozoficznym, i zupełnie się zgadzam, że kultura algebraiczna nie ma nic wspólnego z kulturą filozoficzną. Rachować umiały nawet konie elberfeldzkie. Jednakże rozprawki Chwistka nie mam, ponieważ numerów Masek użyłem do jakiegoś potocznego celu, a czytając recenzję, chciałbym porównać jej tekst z oryginałem. Stąd bardzo bym Cię prosił, abyś był taki łaskaw i przysłał mi równocześnie z recenzją także i rozprawę Chwistka. Nie uszkodzę i oddam. Odeślę, jeśli trzeba ${ }^{32}$.

W tym momencie zapaliło się czerwone światełko u Ingardena. Wiedział, że zadzierając z Chwistkiem, potęguje własny spór z akademikami z Warszawy. Nie przeraził się jednak, lecz cierpliwie czekał na kolejne wieści. Oczywiście wysłał to, o co prosił Witwicki. Z kolejnego listu Witwickiego dowiedział się nieco więcej o szerszym kontekście związanym z publikacją książki Chwistka. Chodziło o jego starania, które podjął na Uniwersytecie Warszawskim w sprawie własnej habilitacji. Znalazł tam zacnych sojuszników dla swojego pomysłu. Chciał się habilitować z logiki algebraicznej, a mieli mu w tym dopomóc Leśniewski, Łukasiewicz, a nawet Kotarbiński. Witwicki pisał w tej sprawie do Ingardena:

30 Zob. tamże.

31 Szczególnie ważny był list Witwickiego z 23 kwietnia 1922 roku, w: ARI.

32 Zob. tamże. 
Już mam cztery rodzaje rzeczywistości Chwistka. Podał się o habilitację z logiki algebraicznej i Leśniewski bardzo jest za nim. Powiada, że nie może człowieka obciążać, że tam sobie filozofuje, bo przecież i Kotarbiński pisał nonsensy, a jednak itd. Dla Leśniewskiego każda w ogóle filozofia jest chwistkologia, a filozofowanie w wolnych chwilach uważa za zupełnie dopuszczalne. Można je każdemu wybaczyć, jeżeli poza tym pisze rzeczy tak wysoce inteligentne, jak logikę matematyczną bez zasady redukcji i I tomu Russela bez czegoś tam. Na recenzję Twoją jestem bardzo ciekaw. Ja jestem bardzo przeciwny temu, żeby do kontaktu z młodzieżą od góry dopuszczać typy ambitne a niesumienne. Chwistek robi na mnie to wrażenie. Niestety, trudno takie wrażenie wyniesione z rozmów ustnych, z obcowania osobistego uzasadniać przed forum wydziału wobec zwolenników danego gościa. Łukasiewicz się waha, a Kotarbiński nie wiem, co myśli ${ }^{33}$.

Z niepokojem oczekiwał Ingarden na kolejne wieści z Warszawy. Wstrzymał się nawet z odpowiedzią na replikę Chwistka. Uczynił to jednak nie dlatego, że bał się reakcji środowiska. Miał wsparcie Witwickiego i jego starania popierał Twardowski. Nie chciał jednak wchodzić dalej w konflikt z samym zainteresowanym. Temperament adwersarza nie wróżył niczego dobrego, a spór mógł w jednej chwili przerodzić się we wcześniejszy dramat paryski. Co prawda pojedynki na broń palną i szable nie były już wówczas w modzie, lecz kto znał bliżej Chwistka, wiedział, że ten jest do wszystkiego zdolny. Dokładnie 17 maja 1922 roku przyszły kolejne wieści z Warszawy od Witwickiego. Donosił on w długim liście do Ingardena:

Zatem Chwistek po zażartej dyskusji przepadł, z powodu braku kwalifikacji osobistych, jako kandydat do docentury w Warszawie. Jestem przekonany, że będzie najdokładniej wiedział, co mówiłem i jakimi słowy, mimo tajemnicy obrad Wydziału. Zupełnie poza obradami Wydziału i niezależnie od nich powiedzieć jestem gotów każdemu, że Nuż w brzuchu wystarcza, żeby kogoś zdyskwalifikować jako nauczyciela w jakiejkolwiek szkole. Jego działalność publiczna wydaje mi się nie kierunkiem artystycznym, tylko działaniem na szkodę kultury europejskiej i polskiej tym samym. Jeżeli czymś jest kultura europejska, ja mam jakieś jej poczucie. Gdybym przynajmniej wierzył, że on z głębokiego przekonania pisze i maluje to, co pisze i maluje. Nie mogę się jednak oprzeć przekonaniu, że to jest wszystko udawane, dla osiągnięcia takiego czy innego efektu. Ciekawe pobłażanie na tym punkcie u Łukasiewicza i Leśniewskiego. Leśniewski uważa, że wszelka filozofia jest takim samym błazeństwem, jak astrologia, chiromancja czy romanse księżycowe; więc, jeżeli Chwistek błaznuje - to nie robi nic gorszego niż każdy inny, kto jakąkolwiek filozofię uprawia. Łukasiewicz znowu uważa, że Chwistka występy artystycz-

33 Zob. list Władysława Witwickiego do Romana Witolda Ingardena z 3 maja 1922 roku, w: ARI. 
ne i filozoficzne są rewolucyjne wprawdzie, ale to nie powinno nikogo przerażać, bo często najgenialniejsze odkrycia wyglądają rewolucyjnie, jak np. logika trójwartościowa albo teoria Einsteina (którą przecież Ajdukiewicz jednym tchem z Łukasiewiczem wymieniał). Powiada, że my jesteśmy ze starszego pokolenia i nie mamy zrozumienia dla młodych rewolucjonistów, którzy może ciekawe ziarna niosą i cenne. Kotarbiński wybacza Chwistkowi wszelkie noże w brzuchu, bo wybaczyła Katarzyna II Suworowowi to, że piał rano, kiedy wstawał z łóżka. Wygrywał za to bitwy. Podobnie Chwistek ma zdaniem jego wysoką kulturę filozoficzną: russellizmu, a że poza tym w wolnych chwilach błaznuje - to drobiazg. Największe obawy budzi tylko program formistów: "Chcemy szczać we wszystkich kolorach". Gdyby nie to niebezpieczeństwo, że kandydat gotów się kiedyś zeszczać z katedry na czerwono i zielono, ręczę Ci, że byłby przeszedł. Takie wrażenie odniosłem z prywatnych rozmów z profesorami. O posiedzeniu i dyskusji natomiast nic $\mathrm{Ci}$ donieść nie mogę, bo mi nie wolno. Ale i te opinie, które Ci podaję, miej dla siebie i nie zdradzaj się z ich znajomoscią. Ja mam to przekonanie, że przenikliwa a bezwzględna krytyka dobrze zrobi i atmosferze intelektualnej w Polsce, i jemu samemu. A przyślij mi tę recenzję. Ja Ci powiadam, że wszystko się zaczęło od podkopania rzekomego zasady sprzeczności. Dziś logika Arystotelesowa uchodzi za jeden z wielu możliwych i zależnych od gustów systemów. Cóż dziwnego, że różne Chwistki mogą hulać. Gdzież ramy jakiekolwiek i gdzie układ rzędnych bezwzględny? ${ }^{34}$

Nic dodać, nic ujaćc. Ingarden po przeczytaniu listu Witwickiego wiedział dokładnie, co ma zrobić. Pochylił się jeszcze raz nad swoją odpowiedzią Chwistkowi i wysłał ją do druku w Przegladzie Filozoficznym. Ukazała się ona dopiero w pierwszym zeszycie z 1923 roku $^{35}$. Była spóźniona wobec ustaleń Chwistka z poprzedniego roku. Niemniej Ingarden dopełnił swego obowiązku. Wypunktował Chwistka w jedenastu paragrafach. Pokazał poprzez rzeczową argumentację błędy w jego pojmowaniu rzeczywistości. Dosadnie mówiąc, sprowadził narwanego adwersarza na ziemię. Odpowiedź Ingardena ukazała się wraz ze sprostowaniem redakcji Przegladu Filozoficznego, która informowała, że tekst Ingardena powinien ukazać się w dziale polemik wraz z repliką Chwistka w czwartym zeszycie z 1922 roku $^{36}$. Jednocześnie Ingarden zapowiedział się u Twardowskiego w Ruchu Filozoficznym ze swoją drugą

34 Zob. list Władysława Witwickiego do Romana Witolda Ingardena z 17 maja 1922 roku, w: ARI.

${ }^{35}$ Zob. Roman W. Ingarden, „Uwagi do «Krótkiej rozprawy itd.»", Przeglad Filozoficzny 26, 1-2 (1923): 100-104. Zob. też listy Mariana Borowskiego do Romana Witolda Ingardena z końca 1922 roku, tj. listy z 10 listopada 1922 roku, 29 listopada 1922 roku, 8 grudnia 1922 roku, 11 grudnia 1922 roku, w: ARI.

36 Zob. tamże, a także trzy listy Mariana Borowskiego do Romana Witolda Ingardena z 30 stycznia 1923 roku, 6 lutego 1923 roku, 10 lutego 1923 roku, w: ARI. 
recenzją pracy Chwistka. Ukazała się ona również w 1923 roku $^{37}$. Satysfakcję miał z tego zwłaszcza Twardowski, gdyż nie darzył sympatią Chwistka, który w późniejszym czasie napsuł krwi zarówno jemu, jak i Ingardenowi.

Po tych wydarzeniach Chwistek przestał na pewien czas walczyć z Ingardenem, Twardowskim i akademikami warszawskimi. Zaszył się ponownie w Krakowie. Nosił jednak w sercu zadrę. Miał żal do Witwickiego i wiedział, że to Twardowski ze Lwowa kierował całą sprawą. Mógł traktować swoją porażkę w Warszawie jako wynik spisku. Dziwił się, że Leśniewski, Łukasiewicz czy też Kotarbiński nie wsparli go w jego staraniach. Zapamiętał jednak sobie młokosa z Torunia, który stanął mu na drodze do filozoficznej kariery. Do dalszych wystąpień Chwistka i jego stronników przeciwko Ingardenowi miało dochodzić w późniejszych latach ${ }^{38}$.

\section{Bibliografia}

Amtliches Verzeichnis des Personals und der Studierenden der Königl, Georg-August-Universität zu Göttingen. Auf das halbe Jahr von Ostern 1909 bis Michaelis 1909. 1909. Göttingen: Dieterich'sche Univ.-Buchdruckerei.

Chrobak Karol. 2004. Niejedna rzeczywistość. Racjonalizm krytyczny Leona Chwistka. Kraków: inter.

Chwistek Leon. 1922. „Krótka rozprawa z panem Romanem Ingardenem, doktorem uniwersytetu fryburskiego". Przeglad Filozoficzny 25 (4): 540-544.

Chwistek Leon. 1918. „Wielość rzeczywistości w sztuce”. Maski 1-4: 38-58.

Chwistek Leon. 1921. Wielość rzeczywistości. Kraków-Jasło: Zakład Graficzny „Wisłoka".

Chwistek Leon. 1961. Pisma filozoficzne i logiczne. T. 1. Warszawa: Państwowe Wydawnictwo Naukowe, 1-105.

Chwistek Leon. 2004. Wybór pism estetycznych, oprac. Teresa Kostyrko. Kraków: Universitas, 3-20.

Dawidowiczowa Alina. 1989. „Zeschnięte liście i kwiat...”. Wspomnienia. Kraków: Wydawnictwo Literackie, 37-38.

Estreicher Karol. 1971. Leon Chwistek. Biografia artysty. Kraków: Państwowe Wydawnictwo Naukowe.

Głombik Czesław. 1999. Husserl i Polacy. Pierwsze spotkania, wczesne reakcje. Katowice: Wydawnictwo Gnome.

37 Zob. Roman W. Ingarden, „Recenzja z Leona Chwistka «Wielość rzeczywistości», Kraków 1921", Ruch Filozoficzny 7, 7-8 (1922/1923): 99-101.

38 Zob. Karol Chrobak, Niejedna rzeczywistość. Racjonalizm krytyczny Leona Chwistka (Kraków: inter esse, 2004), 127-128; Radosław Kuliniak, Mariusz Pandura, Jestem

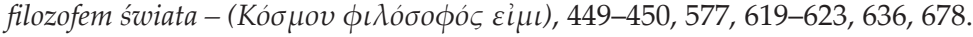


Husserl Edmund. 2005. Einführung in die Phänomenologie der Erkenntnis, hrsg. v. E. Schuhmann. Dordrecht: Springer.

Ingarden Roman W. 1922-1923. „Recenzja z Leona Chwistka «Wielość rzeczywistości», Kraków 1921. Ruch Filozoficzny 7, 7-8: 99-101.

Ingarden Roman W. 1921. „Recenzja z pracy Leona Chwistka «Wielość rzeczywistości»". Przegląd Filozoficzny 25, 3: 467-468.

Ingarden Roman W. 1923. „Uwagi do «Krótkiej rozprawy itd.»”. Przegląd Filozoficzny 26, 1-2: 100-104.

Kahle Reinhard. 2014. Poincaré in Göttingen. W: Poincaré, Philosopher of Science. Problems and Perspectives, M. de Paz, R. DiSalle (eds.). Dordrecht (etc.): Springer.

Kotarbiński Tadeusz. 1922. „Leon Chwistek: Wielość rzeczywistości (recenzja)", Przeglad Warszawski 6: 426-428.

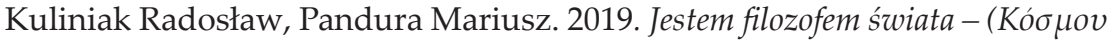

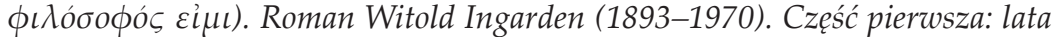
1893-1938. Kęty: Wydawnictwo Marek Derewiecki.

List Kazimierza Twardowskiego do Romana Witolda Ingardena z 26 marca 1922 roku. W: ARI.

List Władysława Witwickiego do Romana Witolda Ingardena z 17 maja 1922 roku. W: ARI.

List Władysława Witwickiego do Romana Witolda Ingardena z 25 lutego 1922 roku. W: ARI.

List Władysława Witwickiego do Romana Witolda Ingardena z 25 lutego 1922 roku. W: ARI.

List Władysława Witwickiego do Romana Witolda Ingardena z 3 maja 1922 roku. W: ARI.

Listy Mariana Borowskiego do Romana Witolda Ingardena z końca 1922 roku, tj. listy z 10 listopada 1922 roku, 29 listopada 1922 roku, 8 grudnia 1922 roku, 11 grudnia 1922 roku. W: ARI.

Listy Mariana Borowskiego do Romana Witolda Ingardena z początku 1922 roku, a dokładnie listy z 13 stycznia 1922 roku i 19 kwietnia 1922 roku. W: ARI.

Murawski Roman 2011. Filozofia matematyki i logiki w Polsce międzywojennej. Toruń: Wydawnictwo Naukowe Uniwersytetu Mikołaja Kopernika.

Nowa Sztuka I, 1 (listopad 1921): 30-31.

Palacz Ryszard. 1999. „Rozdział XXVI. Leon Chwistek, czyli o wielości rzeczywistości". W: Klasycy filozofii polskiej, Warszawa-Zielona Góra: Zachodnie Centrum Organizacji, 299-314.

„Recenzja R. W. Ingardena z pracy L. Chwistka Wielość rzeczywistości”. 1921. Przeglad Filozoficzny, R. 25, 1922, z. 3, 451-468.

Schuhmann Karl. 1977. Husserl-Chronik. Denk- und Lebensweg Edmund Husserls. Dem Haag: Martinus Nijhoff.

Spis nieogłoszonych prac, szkiców, notatek z kwietnia 1928 roku: Czy i jak można poznać obiektywność spostrzeżenia zewnętrznego? (z adnotacją: „II redakcja odczytu na Zjeździe Filoz. W roku 1923, niedokończona, pisana ponownie na wiosnę roku 1925", 36); Streszczenie powyższego od- 
czytu dla Pamiętnika Zjazdu 1923, 5; a także Czy i jak można wykazać obiektywność spostrzeżenia zew. (I red. odczytu maj 1923 roku, s. 27).

Trzy listy Mariana Borowskiego do Romana Witolda Ingardena z 30 stycznia 1923 roku, 6 lutego 1923 roku, 10 lutego 1923 roku. W: ARI.

Twardowski Kazimierz. 2001. Dzienniki, oprac. Ryszard Jadczak, cz. 1: 1915-1927. Toruń: Wydawnictwo Adam Marszałek, nota z 26 sierpnia $1919 \mathrm{roku}, 123$.

\section{Streszczenie}

W latach 1921-1923 doszło na łamach Przegladu Filozoficznego oraz Ruchu Filozoficznego do polemiki między Romanem Witoldem Ingardenem a Leonem Chwistkiem. Dyskusja dotyczyła wydanej właśnie przez Chwistka pracy pt. Wielość rzeczywistości. Napisana przez Ingardena recenzja jest $\mathrm{w}$ tej mierze wzorcem do naśladowania dla młodych adeptów filozofii, który winni uczyć się na niej, jak pisać teksty filozoficzne. Ingarden umiejętnie dyskutuje z Chwistkiem. Nie chce go zdyskredytować, lecz zręcznie wytyka błędy i uchybienia występujące w jego pracy.

Słowa kluczowe: Roman Witold Ingarden, Leon Chwistek, wielość, rzeczywistość.

\section{Summary}

In the years 1921-1923, there was a polemic between Roman Witold Ingarden and Leon Chwistek in the Przeglad Filozoficzny and the Ruch Filozoficzny. The discussion concerned the papers just published by Chwistek, i.e. Multiplicity of Realities. The review written by Ingarden is in this respect a role model for young philosophy students who should learn how to write philosophical texts. Ingarden skilfully discusses with Chwistek. He does not want to ruin his scientific reputation, but dexterously points out errors and omissions occurring in his work.

Keywords: Roman Witold Ingarden, Leon Chwistek, multiplicity, reality. 